\title{
Palliative care needs and experiences of people in prison: a systematic review and meta-synthesis
}

Journal: Palliative Medicine

Word count: 4874/5000 (excl headings, quotes, references)

Authors: Isabelle Schaefer, Michelle DiGiacomo, Nicole Heneka, Stacey Panozzo, Tim Luckett, Jane L. Phillips.

\section{Ms Isabelle Schaefer}

University of Technology Sydney

Sydney NSW Australia

\section{A/Prof Michelle DiGiacomo}

University of Technology Sydney

Sydney NSW Australia

\section{Dr Nicole Heneka}

University of Technology Sydney

Sydney NSW Australia

Dr Stacey Panozzo

University of Melbourne

Melbourne Victoria Australia

\section{Dr Tim Luckett}

University of Technology Sydney

Sydney NSW Australia

Prof Jane L. Phillips

Queensland University of Technology

Brisbane Queensland Australia

Address for correspondence and reprints:

Isabelle Schaefer

PO Box 123 Broadway

Sydney NSW 2007

Australia

(P) +61 (2) 95148049

(E) Isabelle.schaefer@uts.edu.au 
Palliative care needs and experiences of people in prison: a systematic review and meta-synthesis

Journal: Palliative Medicine

Word count: $4875 / 5000$ (excl headings, quotes, references) 


\section{ABSTRACT}

Word count: 248 / 250 (excluding headings)

Background: Globally, the prison population is growing and ageing, as is the need for palliative care. Yet, little is known about how people in prison perceive palliative care provision in prison.

Aims: To identify the: i) perceptions of palliative care provision and dying in custody by people in prison; and ii) perceived barriers and facilitators of person-centred palliative care provision in prison.

Design: A systematic review and meta-synthesis was registered and undertaken in accordance with the reporting guidelines.

Data Sources: Keywords and MeSH headings encompassing i) palliative care, end-of-life care, death; and ii) prison; were used to search Pubmed, Medline, CINAHL, PsycINFO, Web of Science, $\mathrm{CINCH}$ and ProQuest Central. Articles published in English, from high income countries, and containing raw qualitative data exploring perceptions of people in prison of palliative care in custody were included. Findings were reporting according to the ENTREQ guidelines.

Findings: Of the 2193 articles identified, 12 were included. Key experiences of people in prison regarding palliative care related to two themes: 1 ) expectations versus experiences of palliative care; and 2) prison context complicates access to and provision of palliative care. People in prison with palliative care needs want to feel safe, cared for, and acknowledged as they face an expected death due to a progressive illness. The prison environment can severely restrict access to palliative care, leaving people in prison feeling isolated and powerless.

Conclusions: People in prison expect to receive high-quality palliative care, but their experiences often do not match their expectations. Numerous structural and organisational challenges complicate the provision of palliative care in prisons, limiting accessibility of care.

Key Words: Prisons, Prisoners, Palliative Care, Terminal Care, Hospice Care

Supplementary files:

1) Search strategy

2) Coding tree

3) COREQ results spreadsheet

\section{Key statements}

\section{What is already known about the topic?}

- The global prison population is growing and ageing, and are generally in poorer health than people in the community.

- There is an increasing need for palliative and end-of-life care for people in prison with advanced, life-limiting illnesses.

- Palliative care provision in prison is highly variable, with different jurisdictions employing different models of care.

\section{What this paper adds?}

- People in prison expect to receive palliative care of the same quality and accessibility as they would receive in the community, but often described that their experiences did not reflect this.

- The prison environment impacted every aspect of palliative care provision in prison, and created additional barriers to care provision. 


\section{Implications for practice, theory or policy?}

- There is a critical need to improve provision of evidence-based, person-centred palliative care in prisons globally by identifying jurisdictionally-specific best practice care strategies based on principles of palliative care.

- Strategies to improve care should address systemic policy, organisational and structural barriers in the prison system, and be specifically designed for the prison environment. 


\section{Introduction}

Since the AIDS crisis, ${ }^{1-4}$ the need for palliative care in prisons has escalated, including in high income countries such as Australia ${ }^{5}$, the United Kingdom (UK) $)^{6}$, the United States (US) ${ }^{7}$ and Canada ${ }^{8}$.

Globally, the number of older people serving sentences is increasing disproportionately to the general population..$^{3,9-14}$ The introduction of mandatory minimum sentences ${ }^{15}$, prosecution of historical crimes, ${ }^{13,16}$ limited access to early release, ${ }^{16,17}$ and harsher sentences for repeat offenders ${ }^{18}$ have all contributed to the rising number of older people in prison.

Older people in prison are generally in poorer health than equivalent community populations, because of risk factors such as high rates of smoking, alcohol and substance use, housing insecurity and access to or underutilisation of healthcare services. ${ }^{19,20}$ This leads to premature ageing, wherein agerelated illnesses occur approximately ten years earlier than in the general population. ${ }^{16,21}$ Consequently, people in prison experience high rates of chronic disease requiring intensive management and a palliative approach to care in the last year of life. ${ }^{14,22}$

In high income countries, strategies for delivering palliative care to people in prison differ substantially. Healthcare provision may be administered by national $\left(\mathrm{UK}^{23}\right.$, $\left.\mathrm{France}^{24,25}\right)$ or state (Australia ${ }^{26}$, US $^{27}$, Switzerland ${ }^{28}$ ) governments, which leads to considerable variation both between and within countries. In the US, palliative care is often provided onsite in medical facilities or dedicated hospices that may adopt a peer caregiver model of care. Close linkage with community palliative care services to provide in-reach care $\left(\mathrm{UK}^{23,29}\right)$ or tertiary hospitals $\left(\mathrm{France}^{24}\right.$, Australia $\left.{ }^{26}\right)$ are otherwise used. In all instances, people in prison in crisis or with acute care needs are transported to tertiary hospitals.

Providing care to older people in prison is more expensive than care for younger people ${ }^{13,30-32}$ and has not traditionally been a priority. ${ }^{33}$ The cost of providing aged and palliative care in prisons has been identified in Australia, ${ }^{34}$ the UK ${ }^{9}$ and the US, ${ }^{35}$ as has the need for increased funding. ${ }^{9,}{ }^{, 34}$ Resource and funding shortages occur even in the minority of facilities where formal programs and facilities exist. Her Majesty's Inspectorate for Prisons in the UK noted that one prison had "....an excellent palliative care suite..." $(p 8)$ that could not be utilised because there was no dedicated funding. The absence or instability of funding directly impacts the capacity of prisons to provide palliative care.

There is a growing awareness of these issues amongst governments, policy-makers and prison administrations, which has resulted in increased reporting on the health of older people in prison, ${ }^{14,36}$ investigations into barriers to care provision for older people in prison, ${ }^{13,31,32,37}$ and discussions of compassionate release law reform. ${ }^{17,38}$ Further, the development of a national framework for palliative and end-of-life care in UK prisons sets forth principles of care that are respectful, empathetic and person-centred. ${ }^{39}$ However, provision of palliative care in prisons remains of variable accessibility and quality globally, often differing even between institutions in the same jurisdiction. ${ }^{26,27,29}$

A palliative approach requires that the persons usual care team provides holistic, person-centred approach that supports their patients with chronic or life-limiting illnesses and their families to maintain a good quality of life by anticipating and managing their symptoms and distress. ${ }^{40}$ It varies in intensity depending on patient need, is delivered by generalist clinicians and specialist ${ }^{41,42}$ and strongly emphasises patient choice and culturally-safe care. ${ }^{40}$

People in prison have a unique perspective on how palliative care is provided in prison, as they can share and reflect on both firsthand experience from the patient's perspective. As a high proportion of published evidence uses qualitative methods, McParland and Johnston ${ }^{43}$ recommended that a metasynthesis of existing qualitative literature using an approach such as Thomas and Harden's ${ }^{44}$ thematic synthesis be undertaken. This strategy allows common and unique concepts to be identified and mapped between studies, and create a holistic synthesis grounded in both data and theory. This meta-synthesis, while conceptualised independently, directly fills this gap in existing literature. 
Aim

To identify the: i) perceptions of palliative care provision and dying in custody by people in prison; and ii) perceived barriers and facilitators of person-centred palliative care provision in prison.

The systematic review was design to addressed the following research questions:

1. How do people in prison feel about the prospect of dying in prison?

2. What are the experiences of palliative care provision in custody for people in prison?

3. What do people in prison perceive are the barriers and enablers of palliative or end-of-life care in prison from their experiences?

\section{Methods}

\section{Protocol registration and ethical approval}

The protocol for this systematic review was registered with PROSPERO [CRD42020222534]. Ethical approval was not required for this meta-synthesis.

A meta-synthesis was undertaken as this method provides a: systematic means ${ }^{45}$ of consolidating the perspectives of people in prison regarding the provision of palliative care; and allows for the development of new meaning and concepts from constituent data. ${ }^{45}$

\section{Search strategy}

The pre-determined search strategy focused on two domains i) prison and prisoners; and ii) palliative care, end-of-life care, and death), using related MeSH terms, subject headings and keywords as appropriate for Pubmed, Medline, CINAHL, PsycINFO, Web of Science, CINCH and ProQuest Central [See Supplementary table 1]. Pubmed was also searched using the Caresearch palliative care filter, ${ }^{46,}$ ${ }^{47}$ for prison-related MeSH headings and keywords. A hand search of references from included articles was also completed. The search was conducted on 3 June, 2021.

\section{Eligibility criteria}

Articles were included if: they included direct quotes from people in prison in high income countries that were: i) living with palliative or end-of-life care needs; ii) living with advanced progressive illness; or iii) older, and potential future consumers of palliative or end-of-life care in prison; and were published in English in a peer-reviewed journal. Articles from low- and middle-income countries were excluded as published research is extremely limited, and considerations and determinants of palliative care in these settings are likely to be substantially different to those in high income countries. No time limit was imposed on publication date. Data were included if it focused on the experiences, perceptions, or attitudes of these groups towards 'palliative care', and/or 'end-of-life care'. In articles where multiple stakeholders were interviewed, only the data from people in custody was extracted.

Articles were excluded if they: focused on prisoners of war or persons in immigration detention facilities; deaths that were unexpected (suicide, death resulting from violence or sudden medical episode unrelated to chronic illness) or the result of unnatural causes (assisted suicide, voluntary assisted dying, executions or hunger strikes); and/or described care for non-life-limiting illnesses. Further, articles describing programs in which people in prison provided supportive care to peers in prisons were excluded. These were excluded as the volume and comprehensiveness of data warrants a dedicated meta-synthesis, and this model differs significantly from those used outside the US.

\section{Screening}

Screening was conducted in accordance with the PRISMA statement. ${ }^{48}$ After the duplicates and nonprimary research articles were removed, the title and abstract of remaining articles were screened by one reviewer (IS) to remove studies not meeting the eligibility criteria using Endnote 20. The full text 
of the remaining articles was reviewed by one author (IS) to determine final inclusions, which were confirmed during discussion with MD, NH, SP and JP. Disagreements were resolved by group discussion.

\section{Data extraction}

Data were extracted into MS Excel spreadsheets for quality appraisal and coding. Year, lead author's name, country (lead author), title, qualitative method, research question/objective, sample size of people in prison included in interviews or focus groups, and sample size of all participants were recorded. All raw data (quotes) from people in prison were extracted into a separate spreadsheet for coding.

\section{Critical appraisal}

The Consolidated Criteria for Reporting Qualitative Research (COREQ) checklist for reporting qualitative research was used independently by two reviewers (IS and MD) to critically appraise the quality of the studies. Only the qualitative methodology was appraised in the mixed methods studies. Differences were resolved by reviewer discussion until consensus was reached. Articles were not excluded on the basis of critical appraisal results due to the limited available literature.

\section{Data synthesis}

Thematic synthesis was used to inductively distil descriptive and analytical themes from raw qualitative data, using Thomas and Harden's approach. ${ }^{44}$ This method utilises a stepwise process that facilitates strong engagement with the data (free coding), summation of important ideas (descriptive themes, and interpretation to develop core concepts (analytical themes).

At step one, free coding for quotes was undertaken (IS). Free coding allocates keywords to each data item that summarise content and significance. A list of the free codes created was given to two authors (MD, NH), who then independently coded and cross-checked $25 \%$ of the quotes. Differences were discussed and reviewer consensus was reached.

At step two, codes were inductively organised into a hierarchical coding tree [Supplementary file 2] to capture broader ideas that branched into subordinate ideas (IS). Descriptive themes summarising the key ideas of the coding tree were developed, representing possible barriers and facilitators of care (IS, MD, NH) ${ }^{44}$ All themes were constructed from analysis of raw data (quotes) to preserve the voice of participants, rather than adopting themes identified by authors in the included studies.

Descriptive themes informed the development of interpretive analytical themes that allowed new perspectives and concepts to emerge (Step Three). Analytical themes aimed to supplement findings of primary research analysed to reveal further conceptual meaning. ${ }^{44} \mathrm{~A}$ meta-synthesis is designed to be interpretive, not summative, and should develop existing evidence to produce new meaning. ${ }^{45}$

\section{Definitions}

Palliative care is often used synonymously with 'end-of-life care', referring to the last days and weeks of life. There is also significant global diversity as to when palliative care ought to be initiated. This review has adopted a broad definition of palliative care as being the physical, psychological, social and spiritual care that people who are likely to die in the next twelve months may need in the medium (within months) and short (days to weeks) terms. ${ }^{49}$

To acknowledge personhood and reduce bias and stigma, terms such as prisoner, inmate and offender have been increasingly exchanged for phrases such as 'person in prison' or 'person experiencing incarceration'. ${ }^{50}$ 


\section{Findings}

\section{Study selection results}

The search yielded 2193 articles, with one additional record identified via hand searching (Figure 1). Following removal of duplicates, 1132 articles were screened with 1120 excluded because they: were not in English $(n=43)$; were not primary research $(n=531)$; did not focus on people in prison $(n=184)$, or palliative care $(n=317)$; originated in low- or middle-income countries $(n=8)$; or did not contain qualitative research with direct quotes from people in prison $(n=35)$. Two were excluded as the full text articles could not be located. 


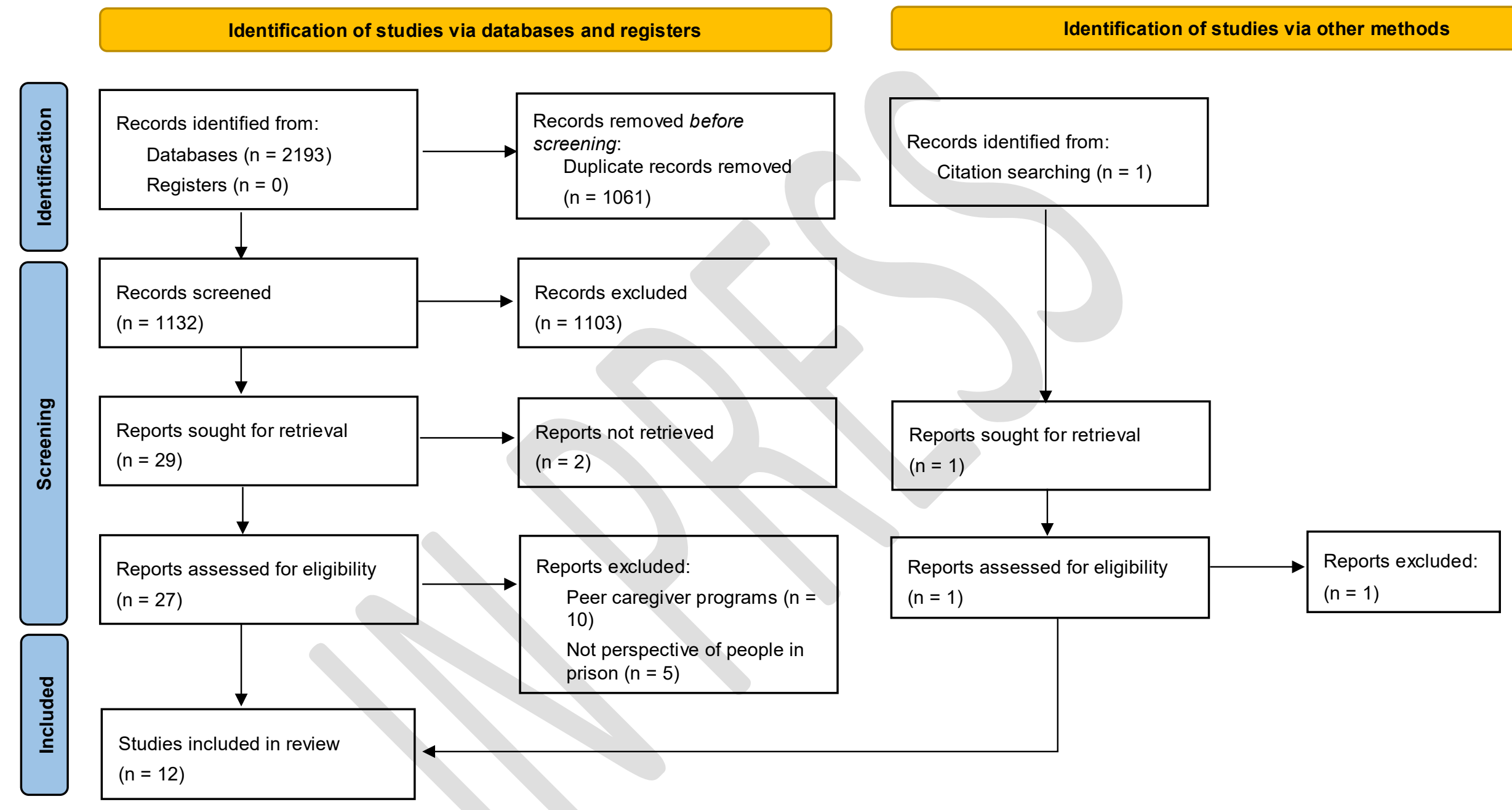

From: Page MJ, McKenzie JE, Bossuyt PM, Boutron I, Hoffmann TC, Mulrow CD, et al. The PRISMA 2020 statement: an updated guideline for reporting systematic reviews. BMJ 2021;372:n71. doi: 10.1136/bmj.n71.

Figure 1: PRISMA flowchart of articles identified by electronic database search. 
Twelve articles published between 2005 and 2018 were included, with half originating in the United States $(n=6)$ (Table 1). No articles reported providing participants with a definition of palliative or endof-life care prior to an interview or focus group. 
Table 1: Included qualitative and mixed methods studies

\begin{tabular}{|c|c|c|c|c|c|c|}
\hline $\begin{array}{l}\text { Year, } \\
\text { Author, } \\
\text { Country }\end{array}$ & Title & $\begin{array}{l}\text { Qualitative } \\
\text { method }\end{array}$ & Objective & Participant details & $\begin{array}{l}\text { COREQ } \\
\text { criteria (32) } \\
\text { fulfilled }\end{array}$ & Key findings reported \\
\hline $\begin{array}{l}2018 \\
\text { Peacock et } \\
\text { al51 } \\
\text { UK }\end{array}$ & $\begin{array}{l}\text { 'We Call it Jail Craft': } \\
\text { The Erosion of the } \\
\text { Protective } \\
\text { Discourses Drawn } \\
\text { on by Prison Officers } \\
\text { Dealing with Ageing } \\
\text { and Dying Prisoners } \\
\text { in the Neoliberal, } \\
\text { Carceral System }\end{array}$ & $\begin{array}{l}\text { Interviews } \\
\text { (individual), } \\
\text { focus } \\
\text { groups }\end{array}$ & $\begin{array}{l}\text { To examine the concept of 'jail craft' drawn on by } \\
\text { correctional officers to manage ageing and dying } \\
\text { people in prison. }\end{array}$ & $\begin{array}{l}(\mathrm{n}=60) \text {, male, people in } \\
\text { prison and other } \\
\text { stakeholders. }\end{array}$ & 11 & $\begin{array}{l}\text { - Correctional officers can manage behaviour of people in prison in } \\
\text { different ways } \\
\text { - Perception of correctional officers that it is not their role to assist in } \\
\text { care provision } \\
\text { - Correctional officers often feel that it is important to provide care, } \\
\text { but that they lack sufficient training and resources } \\
\text { - Relationship and interactions between correctional officers and } \\
\text { people in prison are changing }\end{array}$ \\
\hline $\begin{array}{l}2018 \\
\text { Sanders et } \\
\text { al52 }^{52} \\
\text { US }\end{array}$ & $\begin{array}{l}\text { Agency behind bars: } \\
\text { Advance Care } \\
\text { Planning with aging } \\
\text { and dying offenders }\end{array}$ & $\begin{array}{l}\text { Observation } \\
\text { of } \\
\text { consultation }\end{array}$ & $\begin{array}{l}\text { To develop insight about the opportunities and } \\
\text { needs of offenders in directing the EOL care they } \\
\text { receive and the dying process that they ultimately } \\
\text { experience, which an agentic perspective } \\
\text { facilitates. }\end{array}$ & $\begin{array}{l}(n=20), \text { male, aged } \\
60+\text { years, people in } \\
\text { prison with palliative } \\
\text { care needs. }\end{array}$ & 15 & $\begin{array}{l}\text { - People in prison wanted to implement their preferences for end-of- } \\
\text { life care, and appreciated the opportunity to discuss and create an } \\
\text { ACP } \\
\text { - Previous experiences affected ACP wishes, either their own } \\
\text { experiences or those of others } \\
\text { - Themes of hindered agency included uncertainty of expectation } \\
\text { versus reality, and mistrust of others }\end{array}$ \\
\hline $\begin{array}{l}2018 \\
\text { Sanders et } \\
\text { al }^{53} \\
\text { US }\end{array}$ & $\begin{array}{l}\text { Preparing to Die } \\
\text { Behind Bars: The } \\
\text { Journey of Male } \\
\text { Inmates With } \\
\text { Terminal Health } \\
\text { Conditions }\end{array}$ & $\begin{array}{l}\text { Observation } \\
\text { of } \\
\text { consultation }\end{array}$ & $\begin{array}{l}\text { To report on the inmate experience of } \\
\text { approaching death in prison. }\end{array}$ & $\begin{array}{l}(\mathrm{n}=20) \text {, male, people in } \\
\text { prison with palliative } \\
\text { care needs. }\end{array}$ & 9 & $\begin{array}{l}\text { - Strong feelings of loss, grief and guilt in all aspects of life } \\
\text { - Simultaneous, varied feelings about dying in prison } \\
\text { - Place of death was significant, particularly when uncertain } \\
\text { - Struggle to find meaning in the context of being incarcerated while } \\
\text { approaching death }\end{array}$ \\
\hline $\begin{array}{l}2018 \\
\text { Turner et } \\
\text { a }^{54} \\
\text { UK }\end{array}$ & $\begin{array}{l}\text { Ageing and dying in } \\
\text { the contemporary } \\
\text { neoliberal prison } \\
\text { system: Exploring } \\
\text { the 'double burden' } \\
\text { for older prisoners }\end{array}$ & $\begin{array}{l}\text { Interviews } \\
\text { (individual), } \\
\text { focus } \\
\text { groups }\end{array}$ & $\begin{array}{l}\text { To discuss the effect of neoliberal correctional } \\
\text { policies on ageing and dying in UK prisons. }\end{array}$ & $\begin{array}{l}(\mathrm{n}=60) \text {, male, people in } \\
\text { prison and other } \\
\text { stakeholders. }\end{array}$ & 10 & $\begin{array}{l}\text { - People in prison were often frail and vulnerable, were diagnosed } \\
\text { with one or more health conditions, and had limited mobility } \\
\text { - The prison environment including limited staff and resources } \\
\text { created barriers to care }\end{array}$ \\
\hline $\begin{array}{l}2017 \\
\text { Chassagne } \\
\text { et al24 } \\
\text { FRA }\end{array}$ & $\begin{array}{l}\text { The Collision of } \\
\text { Inmate and Patient: } \\
\text { End-of-Life Issues in } \\
\text { French Prisons }\end{array}$ & $\begin{array}{l}\text { Interviews } \\
\text { (individual) }\end{array}$ & $\begin{array}{l}\text { To understand the viewpoints of prisoners in that } \\
\text { last year of life, and healthcare providers that care } \\
\text { for them; and identify barriers to palliative care. }\end{array}$ & $\begin{array}{l}(\mathrm{n}=14) \text {, male, people in } \\
\text { prison with palliative } \\
\text { care needs. }\end{array}$ & 14 & $\begin{array}{l}\text { - } \quad \text { Access to clinicians can be delayed } \\
\text { - Other people in prison may be asked to provide assistance with } \\
\text { activities of daily living } \\
\text { - Limited resources for comfort care (e.g. pressure mattresses) } \\
\text { - People in prison feel isolated and unsupported } \\
\text { - Difficult to be perceived as a 'patient' rather than person in prison }\end{array}$ \\
\hline
\end{tabular}




\begin{tabular}{|c|c|c|c|c|c|c|}
\hline $\begin{array}{l}\text { Year, } \\
\text { Author, } \\
\text { Country }\end{array}$ & Title & $\begin{array}{l}\text { Qualitative } \\
\text { method }\end{array}$ & Objective & Participant details & $\begin{array}{l}\text { COREQ } \\
\text { criteria (32) } \\
\text { fulfilled }\end{array}$ & Key findings reported \\
\hline $\begin{array}{l}2017 \\
\text { Handtke et } \\
\text { al }^{55} \\
\text { CHE }\end{array}$ & $\begin{array}{l}\text { The collision of care } \\
\text { and punishment: } \\
\text { Ageing prisoners' } \\
\text { view on } \\
\text { compassionate } \\
\text { release }\end{array}$ & $\begin{array}{l}\text { Interviews } \\
\text { (individual) }\end{array}$ & $\begin{array}{l}\text { To present the views of ageing prisoners on } \\
\text { compassionate release using qualitative } \\
\text { interviews }\end{array}$ & $\begin{array}{l}(n=35) \text {, male, } 50+ \\
\text { years old }\end{array}$ & 18 & 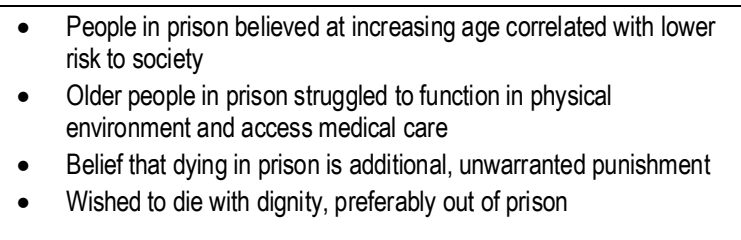 \\
\hline $\begin{array}{l}2017 \\
\text { Turner et } \\
\text { al56 }^{56} \\
\text { UK }\end{array}$ & $\begin{array}{l}\text { Palliative Care in UK } \\
\text { Prisons: Practical } \\
\text { and Emotional } \\
\text { Challenges for Staff } \\
\text { and Fellow } \\
\text { Prisoners }\end{array}$ & $\begin{array}{l}\text { Interviews } \\
\text { (individual), } \\
\text { Focus } \\
\text { groups } \\
\text { Mixed } \\
\text { method } \\
\text { study }\end{array}$ & $\begin{array}{l}\text { To discuss issues raised by changing } \\
\text { demographics of prison population, and practical } \\
\text { and emotional challenges for prison officers, } \\
\text { health care staff and fellow prisoners caring for } \\
\text { dying prisoners in custodial environment. }\end{array}$ & $\begin{array}{l}\text { No data; male, people } \\
\text { in prison and other } \\
\text { stakeholders. }\end{array}$ & 4 & $\begin{array}{l}\text { - Physical environment and resources, including staffing, are limited, } \\
\text { and affect care available } \\
\text { - Caring for people in prison with palliative care needs profoundly } \\
\text { affects correctional clinicians and officers }\end{array}$ \\
\hline $\begin{array}{l}2014 \\
\text { Handtke et } \\
\text { al28 }^{28} \\
\text { CHE }\end{array}$ & $\begin{array}{l}\text { Ageing Prisoners' } \\
\text { Views on Death and } \\
\text { Dying: } \\
\text { Contemplating End- } \\
\text { of-Life in Prison }\end{array}$ & $\begin{array}{l}\text { Interviews } \\
\text { (individual) }\end{array}$ & $\begin{array}{l}\text { To investigate elderly prisoners' attitudes towards } \\
\text { death and dying in prison }\end{array}$ & $\begin{array}{l}(n=35), \text { male, aged } \\
50+\text { years }\end{array}$ & 16 & $\begin{array}{l}\text { - Half of sample had previously thought about death in prison, often } \\
\text { in context of suicide } \\
\text { - Attitudes toward death and dying were mixed } \\
\text { - Negative experiences with healthcare in prison were frequently } \\
\text { reported } \\
\text { - Isolation from family barrier to psychosocial support and mending } \\
\text { relationships }\end{array}$ \\
\hline $\begin{array}{l}2014 \\
\text { Loeb et al57 } \\
\text { US }\end{array}$ & $\begin{array}{l}\text { Who Wants to Die in } \\
\text { Here? Perspectives } \\
\text { of Prisoners With } \\
\text { Chronic Conditions }\end{array}$ & $\begin{array}{l}\text { Interviews } \\
\text { (individual) }\end{array}$ & $\begin{array}{l}\text { To examine the values, beliefs, and perceptions } \\
\text { held by current and potential future consumers of } \\
\text { EOL care in prisons to highlight the facilitators and } \\
\text { barriers to providing this essential service. }\end{array}$ & $\begin{array}{l}(\mathrm{n}=21) \text {, male, people in } \\
\text { prison with palliative } \\
\text { care needs. }\end{array}$ & 17 & $\begin{array}{l}\text { - } \quad \text { Connections with others including family provide support } \\
\text { - } \quad \text { Limited resources were available for care needs, difficulties } \\
\text { - } \quad \text { Care depends on attitudes of clinicians/officers on shift } \\
\text { - }\end{array}$ \\
\hline $\begin{array}{l}2009 \\
\text { Deaton et } \\
\text { al58 } \\
\text { US }\end{array}$ & $\begin{array}{l}\text { The effect of health } \\
\text { and penal harm on } \\
\text { aging female } \\
\text { prisoners' views of } \\
\text { dying in prison }\end{array}$ & $\begin{array}{l}\text { Free- } \\
\text { response } \\
\text { survey }\end{array}$ & $\begin{array}{l}\text { To examine the effect of health status and } \\
\text { incarceration on female prisoners' attitudes to } \\
\text { death. }\end{array}$ & $\begin{array}{l}(\mathrm{n}=327), \text { female, aged } \\
50+\text { years }\end{array}$ & 10 & $\begin{array}{l}\text { - Factors such as feeling physically unsafe, poor self-reported } \\
\text { physical/mental health, high number of chronic illnesses } \\
\text { associated with higher death anxiety }\end{array}$ \\
\hline $\begin{array}{l}2005 \\
\text { Aday et al59 } \\
\text { US }\end{array}$ & $\begin{array}{l}\text { Aging prisoners' } \\
\text { concerns toward } \\
\text { dying in prison }\end{array}$ & $\begin{array}{l}\text { Interviews } \\
\text { (individual) }\end{array}$ & $\begin{array}{l}\text { To investigate factors associated with death } \\
\text { anxiety for people in prison aged } 50 \text { years or } \\
\text { more. }\end{array}$ & $\begin{array}{l}(n=102), \text { male, aged } \\
50+\text { years }\end{array}$ & 12 & $\begin{array}{l}\text { - Views about dying in prison vary from fear to acceptance. } \\
\text { - Stigma associated with dying in prison }\end{array}$ \\
\hline
\end{tabular}




\begin{tabular}{|c|c|c|c|c|c|c|}
\hline $\begin{array}{l}\text { Year, } \\
\text { Author, } \\
\text { Country }\end{array}$ & Title & $\begin{array}{l}\text { Qualitative } \\
\text { method }\end{array}$ & Objective & Participant details & $\begin{array}{l}\text { COREQ } \\
\text { criteria (32) } \\
\text { fulfilled }\end{array}$ & Key findings reported \\
\hline $\begin{array}{l}2005 \\
\text { Enders et } \\
\text { al }{ }^{60} \\
\text { US }\end{array}$ & $\begin{array}{l}\text { An Approach to } \\
\text { Develop Effective } \\
\text { Health Care } \\
\text { Decision Making for } \\
\text { Women in Prison }\end{array}$ & $\begin{array}{l}\text { Focus } \\
\text { groups }\end{array}$ & $\begin{array}{l}\text { To identify informational barriers to people making } \\
\text { medical care and treatment decisions, particularly } \\
\text { those with low literacy. }\end{array}$ & $\begin{array}{l}(\mathrm{n}=113), \text { female, age } \\
\text { range not reported }\end{array}$ & 16 & $\begin{array}{l}\text { - } \quad \text { Need for a therapeutic alliance between provider and patient } \\
\text { - Critical to provide audience-appropriate medical information for } \\
\text { those with low health literacy }\end{array}$ \\
\hline
\end{tabular}




\section{Appraisal results}

Included articles fulfilled approximately 13 of the 32 COREQ criteria [Supplementary file 3], indicating poor to moderate quality. All articles reported findings reflecting the data provided and described major and minor themes. Most reported the number of participants $(n=11)$ and provided their demographics $(n=10)$. No articles described the interviewers' characteristics. Only a few $(n=6)$ provided recruitment details and the interview/survey question route $(n=5)$. The methodological approach(es) to qualitative analysis and coding were rarely reported in detail $(n=1)$.

\section{Themes}

Two broad analytical themes and constituent concepts identified during this meta-synthesis (Table 2), namely: 1) expectations versus experiences of palliative care and 2) Prison context complicates access to and provision of care. People in prison expected to receive high quality palliative care, and be able to form a collaborative relationship with clinicians, but often felt this did not match their experience. Dying in prison was seen as an additional and unjustifiable punishment, while their capacity to make choices was strictly limited in prison. Secondly, the prison context, including the physical environment, complicates access to palliative care and thoughts about dying. 
Table 2: Analytical and descriptive themes.

\begin{tabular}{|c|c|c|c|}
\hline Analytical theme & Analytical subthemes & Descriptive theme & Exemplifying quote \\
\hline \multirow[t]{8}{*}{$\begin{array}{l}\text { 1. Expectations versus } \\
\text { experiences of palliative } \\
\text { care }\end{array}$} & \multirow[t]{8}{*}{$\begin{array}{l}\text { a. Expectation of } \\
\text { equitable palliative and } \\
\text { supportive care }\end{array}$} & $\begin{array}{l}\text { Feeling unsafe causes anxiety: perceived lack of psychosocial } \\
\text { and/or medical support from clinicians can result people in prison } \\
\text { with palliative care needs feel vulnerable. }\end{array}$ & $\begin{array}{l}\text { The system has neglected them [people in prison who have } \\
\text { died]....It makes me feel like l'm next.58 }\end{array}$ \\
\hline & & $\begin{array}{l}\text { Unmanaged pain reduces quality of life: whether as a result of } \\
\text { insufficient or unavailable medication, access, communication or } \\
\text { policy. }\end{array}$ & $\begin{array}{l}\text { [I said,] "Listen, when I tell you that I really am in pain, it } \\
\text { means that there is something, I am not messing around!" } \\
\text { And then they told me, "Okay, but it wasn't that serious." I } \\
\text { said, "Sorry, what?!"28 }\end{array}$ \\
\hline & & $\begin{array}{l}\text { Perceived clinical experience and training: people in prison } \\
\text { believed that some clinicians were not adequately trained to meet } \\
\text { their needs, particularly during emergencies. Given their inability } \\
\text { to choose their own clinicians, this was a cause of despair and } \\
\text { hopelessness. }\end{array}$ & $\begin{array}{l}\text { They went into the room and tried to resuscitate her. They } \\
\text { put the tube down, and instead of running it into her airway, } \\
\text { they run it down into her stomach and blew her up with the } \\
\text { air that they was expecting to be putting in her lung. }{ }^{58}\end{array}$ \\
\hline & & $\begin{array}{l}\text { Healthcare responsiveness: a person in prison's perception of } \\
\text { responsiveness to self-reported needs or crises affects their view } \\
\text { of the effectiveness of care, and feeling of safety and security. }\end{array}$ & $\begin{array}{l}\text { I have seen a woman have a stroke and left to lie on the } \\
\text { ground while medical personnel walked to the person and } \\
\text { smoked and joked as they walked. } \text {. }^{58}\end{array}$ \\
\hline & & $\begin{array}{l}\text { Clinician attitudes: patients felt that the attitudes of clinicians } \\
\text { influenced the care that was available, resulting in variations in } \\
\text { care depending on staff on shift, This affected how patients } \\
\text { perceived the quality of care, and how 'cared for' they felt. }\end{array}$ & $\begin{array}{l}\text { When an inmate's health goes downhill, the attitude is, 'well, } \\
\text { it's another one gone that we don't have to put up with no } \\
\text { more. } 57\end{array}$ \\
\hline & & $\begin{array}{l}\text { Adequacy of staffing: using insufficient or inappropriate staff } \\
\text { who are not trained to manage people with palliative care limits } \\
\text { support and medical care available. }\end{array}$ & $\begin{array}{l}\text { Guards need to be trained... sometimes guards from the } \\
\text { hole [solitary confinement area of the prison where prisoners } \\
\text { with disciplinary issues are held] will come in and substitute } \\
\text { in the medical unit that's been a problem. }{ }^{77}\end{array}$ \\
\hline & & $\begin{array}{l}\text { Cultural focus on security: prison ethos and culture determine } \\
\text { balance between care and custody priorities, and can be } \\
\text { influenced by public opinion and political motives. }\end{array}$ & $\begin{array}{l}\text { You know, there are these strict visiting hours, right? And } \\
\text { they are stubbornly following these visiting hours and ... } \\
\text { That's because for security this is a big risk, but I have the } \\
\text { feeling, if something doesn't fit into their routine, that needs } \\
\text { more work, then, it's simply not possible. }{ }^{28}\end{array}$ \\
\hline & & $\begin{array}{l}\text { Medical resource shortages cause anxiety: being unsure if } \\
\text { supportive or life-saving medical equipment would be available }\end{array}$ & $\begin{array}{l}\text { They die in here all the time. Even young people die in here } \\
27 \text { years old from diseases and heart attacks. Here, they are }\end{array}$ \\
\hline
\end{tabular}




\begin{tabular}{|c|c|c|c|}
\hline Analytical theme & Analytical subthemes & Descriptive theme & Exemplifying quote \\
\hline & & $\begin{array}{l}\text { when needed was very concerning for people in prison, } \\
\text { particularly those who relied on oxygen who felt vulnerable to } \\
\text { events that may affect their supply. }\end{array}$ & $\begin{array}{l}\text { not very well equipped to handle a heart attack. They have } \\
\text { to go call somebody in to get you. They got an EKG } \\
\text { machine, but still, that ain't nothing if you are having a heart } \\
\text { attack. You know, they need a medical hospital here. }{ }^{58}\end{array}$ \\
\hline & & $\begin{array}{l}\text { Family psychosocial support: People in prison are separated } \\
\text { from the support of their families who provide a humanising } \\
\text { influence in a difficult and isolating environment. }\end{array}$ & $\begin{array}{l}\text { One of the greatest anxieties for older prisoners is becoming } \\
\text { terminally ill in prison, cut off from the loving support of } \\
\text { families and subject to a regime that can be unkind. }{ }^{54}\end{array}$ \\
\hline & & $\begin{array}{l}\text { Patient is responsible for voicing their needs (Patient self- } \\
\text { advocacy): a patient ought to guide clinical care in partnership } \\
\text { with clinicians. Patients perceived that their own investment in } \\
\text { care by effective communication generates higher quality care. } \\
\text { Creates a shared responsibility with clinicians in which each party } \\
\text { has a respective role that combines to facilitate care. }\end{array}$ & $\begin{array}{l}\text { If you don't do anything for yourself, you can't expect to get } \\
\text { a lot of help. Some want to be catered to and it doesn't work } \\
\text { well, but if you help yourself, others will help you... }{ }^{57}\end{array}$ \\
\hline & $\begin{array}{l}\text { b. Building a connection } \\
\text { with clinicians in prison }\end{array}$ & $\begin{array}{l}\text { Quality of communication influences therapeutic alliance: } \\
\text { influenced patient's understanding of their illness, and therefore } \\
\text { their understanding of prognosis and actions around Advance } \\
\text { Care Planning. Good communication engendered trust. }\end{array}$ & $\begin{array}{l}\text { I don't know much about what is going on with me ... } \\
\text { doctors say little. They say the chemo will make the pain } \\
\text { better. No one has really told me how bad it is ... I don't feel } \\
\text { that sick but everyone is telling me that I am really sick. }{ }^{52}\end{array}$ \\
\hline & & $\begin{array}{l}\text { Building rapport: people in prison need to feel that their } \\
\text { clinicians empathise with them, view them as worthy of care and } \\
\text { appreciate the difficulties of being ill in prison. High staff turnover } \\
\text { complicates relationship-building. }\end{array}$ & $\begin{array}{l}\text { We're lookin' for somebody we can open up to and can talk } \\
\text { to ... understand us and confide in them ... someone who } \\
\text { cares. }^{60}\end{array}$ \\
\hline & & $\begin{array}{l}\text { Feeling ignored or unseen: Consultation with clinicians can be } \\
\text { rushed or not address all of a patient's issues. }\end{array}$ & $\begin{array}{l}\text { I have five life-threatening illnesses-so my whole problem } \\
\text { is not asking the questions, it's being recognized 'cause I } \\
\text { bring issues to my doctor. } 60\end{array}$ \\
\hline & $\begin{array}{l}\text { c. Differentiation between } \\
\text { just and unjust } \\
\text { punishment }\end{array}$ & $\begin{array}{l}\text { Expectation of equitable care: people in prison expect to } \\
\text { receive care equitable to the community, and the prison system is } \\
\text { responsible for providing a safe environment and sufficient } \\
\text { medical care. }\end{array}$ & We shouldn't have to suffer. ${ }^{57}$ \\
\hline & & $\begin{array}{l}\text { Compassionate release is humane: allowing release at the } \\
\text { end-of-life is benevolent and respectful of a person's humanity. }\end{array}$ & $\begin{array}{l}\text { I agree that when you have done some kind of crap, you } \\
\text { need to pay for that. But at one point, let's say, at } 60 \text { years } \\
\text { and it is clear that you are suffering from heart disease and } \\
\text { diabetes ... that you have cancer or devil knows what and }\end{array}$ \\
\hline
\end{tabular}




\begin{tabular}{|c|c|c|c|}
\hline Analytical theme & Analytical subthemes & Descriptive theme & Exemplifying quote \\
\hline & & & $\begin{array}{l}\text { you only have a year left, then outside it is. He should enjoy } \\
\text { this last time. }{ }^{55}\end{array}$ \\
\hline & & $\begin{array}{l}\text { Social considerations should not affect compassionate } \\
\text { release: such as public perception and improving statistics. }\end{array}$ & $\begin{array}{l}\text { People from the street may not agree with legal decisions, } \\
\text { [but] this is none of their business. }{ }^{55}\end{array}$ \\
\hline & $\begin{array}{l}\text { d. Capacity to make } \\
\text { choices is severely } \\
\text { limited }\end{array}$ & $\begin{array}{l}\text { Asserting control after death: people in prison express } \\
\text { control where choices are available (suicide/voluntary } \\
\text { assisted dying, funeral and burial plans). These actions or } \\
\text { plans provided an opportunity to make choices without the } \\
\text { influence of the prison system, a means of self-determination } \\
\text { in a typically restrictive environment. }\end{array}$ & $\begin{array}{l}\text { If I can't be in the same shape [as I am now], then no CPR. } \\
\text { Don't want a wheelchair or a machine. }{ }^{52}\end{array}$ \\
\hline & & $\begin{array}{l}\text { Small freedoms are beneficial: help people in prison feel } \\
\text { supported. Being allowed to undertake small activities to } \\
\text { pass time, and being given preferred foods occasionally } \\
\text { such as ice cream were greatly appreciated, and mentioned } \\
\text { as positive elements of care provided. }\end{array}$ & $\begin{array}{l}\text { [My] job is the only thing I do to pass the time and give back } \\
\text { to others. }{ }^{53}\end{array}$ \\
\hline \multirow[t]{6}{*}{$\begin{array}{l}\text { 2. The prison context } \\
\text { complicates access to and } \\
\text { provision of care }\end{array}$} & $\begin{array}{l}\text { a. Physical environment } \\
\text { complicates quality of } \\
\text { care }\end{array}$ & $\begin{array}{l}\text { Physical environment affects quality of life: poor sleeping } \\
\text { arrangements or lack of facilities to manage high dependency } \\
\text { patients in general housing units may cause unnecessary } \\
\text { discomfort, and indignity. }\end{array}$ & $\begin{array}{l}\text { Rooms in the infirmary are really not adequate there's no } \\
\text { heat in there [I] had to sleep under three blankets. }{ }^{57}\end{array}$ \\
\hline & \multirow[t]{5}{*}{$\begin{array}{l}\text { b. Dying in prison adds } \\
\text { complexity to mortality }\end{array}$} & $\begin{array}{l}\text { Dying in prison is a double burden: dying in prison perceived } \\
\text { as additional to their punishment of imprisonment, and unjust } \\
\text { given how the privations of imprisonment affected care. }\end{array}$ & $\begin{array}{l}\text { On [prison wing] is an inmate of } 91 \text { years [Respondent's } \\
\text { emphasis]. He is mentally unstable and should not be in } \\
\text { prison. }{ }^{54}\end{array}$ \\
\hline & & $\begin{array}{l}\text { Uncertainty and fear about dying process: lack of } \\
\text { psychosocial support can compound fears of dying alone, or in } \\
\text { pain, and that death will not be dignified in an environment where } \\
\text { people in prison feel vulnerable. }\end{array}$ & $\begin{array}{l}\text { My concern is not with what happens after death, but with } \\
\text { the process of dying . . the pain, the dignity. }{ }^{59}\end{array}$ \\
\hline & & $\begin{array}{l}\text { Inevitability and hopelessness of declining health: of both self } \\
\text { and others causes anxiety. After falling ill, people in prison have } \\
\text { limited expectations about the success of medical interventions. }\end{array}$ & $\begin{array}{l}\text { I am old and [have] done } 22 \text { years in here. I have gotten } \\
\text { older and sicker every year. }{ }^{58}\end{array}$ \\
\hline & & $\begin{array}{l}\text { Causing pain and shame: People in prison were concerned at } \\
\text { the impact of their actions and death in prison on their family, and } \\
\text { the pain they would cause. }\end{array}$ & Dying here is a disgrace to my family. ${ }^{59}$ \\
\hline & & Fear of dying in prison: as ultimate failure. & It means that I have failed God. ${ }^{58}$ \\
\hline
\end{tabular}




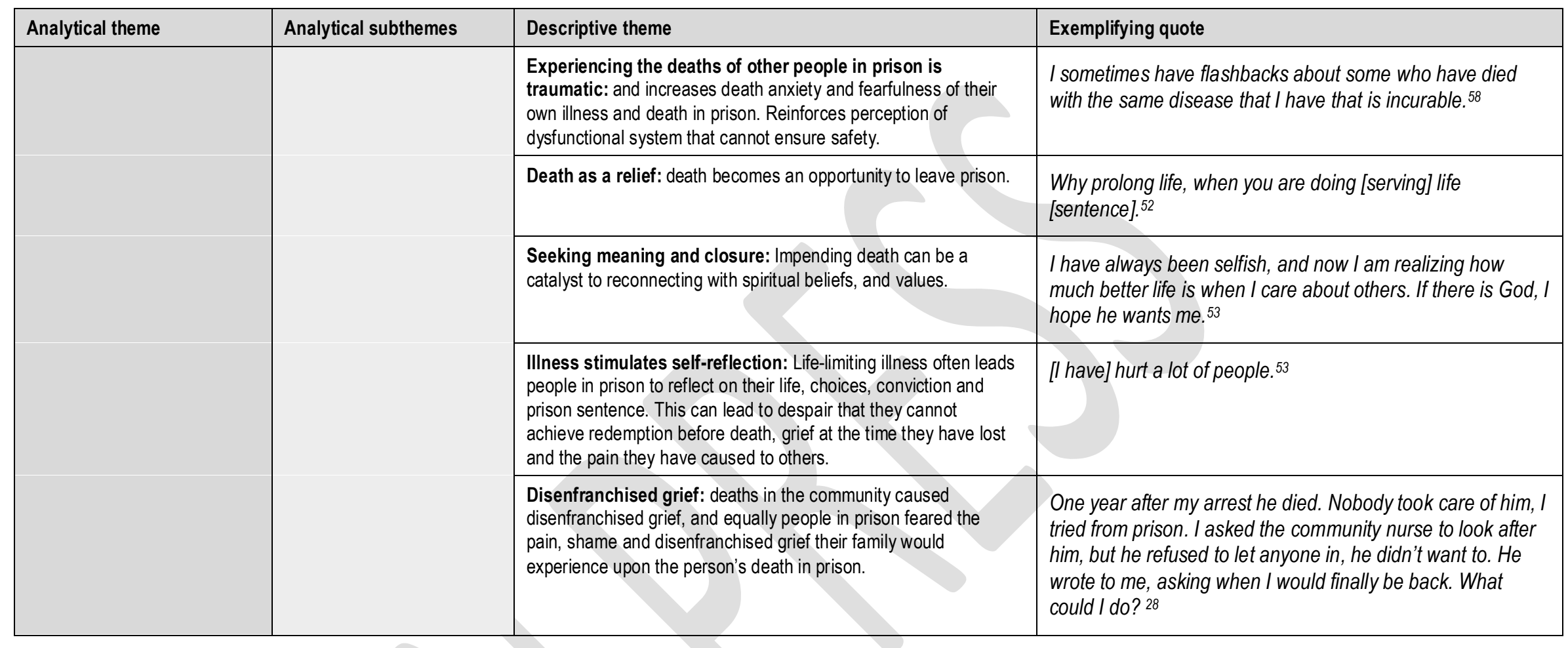




\section{1) Expectations versus experiences of palliative care}

Participants expected to have the same access to high-quality palliative care in prison as they would in the community. This extended to clinical care, patient-provider relationships, the capacity to make choices, and the prioritisation between care and custody. Many reported experiences that did not align with these expectations, and discussed incidents to explain their fears.

\section{Expectation of equitable palliative and supportive care}

Access to routine and acute palliative care in prison was limited by internal procedures that restricted admission to the infirmary, and mandated overnight confinement of people in prison to their cells. Some people reported long delays ("...I had to wait two weeks..." [p 68] $]^{24}$ ) before access to a medical consultation or that they "may not have [a medical problem] checked out because [they] couldn't afford the co-pay." ( $\mathrm{p} 178)^{57}$

They also described feeling powerlessness during a medical emergency because they were entirely dependent on correctional officers and clinicians to promptly respond to the emergency, which did not always happen. Fear of inadequate medical care during an emergency added to their distress and hopelessness:

To be so sick and so locked up, and you don't have any way of getting help, and you look out there and you don't see a guard anywhere for maybe 20 or 30 minutes, and you think what if I have a heart attack and I can't get out.

That really scares me. ${ }^{58}$ ( $p$ 59)

Experiencing or observing delayed medical assistance provoked an acute fear of how their future care would be managed. Participants were frustrated when calls for medical care were initially unanswered:

Get a guard! Get a guard! She's foaming at the mouth!" The guard went running in there, looked in the door and said, "I want you to roll over and shut up! I am tired of hearing you beat on this door." She said, "I'm telling you, she's dying. Her eyes are rolled back in her head, She's dying." So she finally, after 20 minutes, got on the radio and got another guard up there. ${ }^{58}$ ( $p$ 60)

Managing complex palliative care symptom needs was perceived to be challenging in the prison setting, especially in relation to pain. Many participants had observed their peers dying in pain: "... he suffered badly, he didn't deserve to suffer the way he did." ${ }^{57}$ ( $p$ 179). Others reflected that avoiding pain was "...the most important thing for these patients..." prison clinicians were reluctant to prescribe opioids at the cost of quality of life:

Lots of folks are in pain but they have a policy where they don't want folks to get addicted to narcotics ... they try things like extra strength Tylenol or Ultram ... they're [dying prisoners] really suffering and really in pain. ${ }^{57}$ (p 178)

Pain was difficult to manage at night, as onsite clinicians were not always available, leaving people in prison to cope on their own: "Night-time there was no care at all... And as for this pain relief-what pain relief? That's a joke." ${ }^{.56}$ ( $p$ 64)

Others felt that clinicians cared, but were also restricted by the prison environment and policies:

I don't think that the staff don't care because, to be honest with you, I think the staff do care, ... but I think it's just there's no [pause] there's no system in place for anybody who is in real bad pain. ${ }^{56}$ ( $p$ 61)

Despite attempting to communicate significant pain, participants often felt ignored and neglected when they could not receive sufficient pain medication, as "...they left me alone with my illness ... I had leukemia and they gave me paracetamol, I was suffering." ${ }^{24}$ ( $\mathrm{p} 70$ )

Absence of supportive care was also problematic. Supportive care in prison focused on opportunities to connect with others and engage in meaningful activities. 
Overwhelmingly, participants wished for more opportunities to see their family. Connecting with family members was grounding and comforting, while separation in last weeks and months of life "...

diminishes your existence. You're not with the people who truly love you ... You feel you are only half the human you should be. ${ }^{59}$ ( $p$ 209) Participants were keenly aware of the impact that their death in prison would have on their families, worrying about causing pain, shame and further harm. ${ }^{53,58,59}$

Several participants reported that clinicians made efforts to "...try and keep us guys a little closer [to home], because seeing your family is important.".57 ( $\mathrm{p}$ 176), and were "good about calling families and about letting families come and stay with the inmates." ${ }^{n 7}(\mathrm{p} 176)$. Participants wanted reduced restrictions on visitation during palliative care to access psychosocial support. ${ }^{28}$ Some believed that these requests were refused on principle because "...if something doesn't fit into their [correctional officers] routine, that needs more work, then it simply isn't possible." ${ }^{28}$ ( $\left.\mathrm{p} 380\right)$ This was true when people in prison wished to visit a peer in the medical unit, as "...there's inconsistency, some of the COs will let you visit a very sick inmate who's in the infirmary and some of them won't..." ${ }^{57}$ ( $p$ 177)

Opportunities to socialise within the prison family either casually or through a job, educational program or activity were often sought to access support and pass the time. One participant recalled another person in prison with a terminal illness he attended classes with:

He wanted to get his GED [General Education Diploma] [I] was going to be working with him to help him to pass his GED but never had the opportunity because the young man died [of] end stage renal disease he was scared to death of dying what can you do? I just try to talk to them...57 ( $p$ 179)

Building relationships with others through work or activities provided a welcome distraction from health concerns and prison tedium, in addition to improving perceptions of quality of care. ${ }^{57}$

\section{Building a connection with clinicians in prison}

The dynamic between patient and provider was unavoidably altered by the prison environment. Two concerns arose concerning the therapeutic alliance: the nature of the clinical relationship, and clinical communication.

Building a constructive and compassionate relationship between clinician and patient was particularly problematic during incarceration. Female participants described feeling vulnerable during consultations, as "I guess because I feel they are superior, I forget everything I went in there for. I can speak my mind to the next person, but when I sit in that doctor's office, I'm just little." ${ }^{\text {" } 0}$ ( $\mathrm{p} 437$ )

Mistrust of providers by patients also limited the relationship, particularly when participants felt it impeded care. Administrative barriers to care such as requiring paper forms, ${ }^{57}$ prohibitive copayments ${ }^{57}$, and protocols restricting opioid use ${ }^{28}$ were perceived as arbitrary and unnecessarily harsh. One participant was fearful that "they are...still testing drugs on inmates [Inmate cries]. It's so hard." 24 ( $p$ 70). Observing an apathetic response to crises from clinicians and correctional officers was especially upsetting. A participant recalled seeing ".... woman have a stroke and left to lie on the ground while medical personnel walked to the person and smoked and joked as they walked." ${ }^{\prime 58}(p 60)$ One participant felt devalued and alone, that "...they did not want to care for me..." ${ }^{24}(\mathrm{p} 70)$. Hopelessness about quality of care led some to despair, believing that "If I get sick, I know I will die in here." ${ }^{58}$ ( $p 59$ ). Empathetic, respectful and compassionate relationships were highly valued, but often reportedly absent. This also varied by providers on shift, as "...if you get the right nurse, you'll get good care....57 ( $p$ 177).

Participants wished for clear and respectful communication with their clinicians to adequately convey complex medical information:

You sometimes gotta talk to me like l'm a child. Don't talk to me like I'm a professor-break it on down, be simple with me. I'm a simple person with a complicated disease-You know what I'm sayin? ${ }^{60}$ (p 438)

When communication broke down, Participants could be left with little understanding of their condition: "I don't know much about what is going on with me ... [the] doctors say little. ...No one has 
really told me how bad it is ... I don't feel that sick, but everyone is telling me that I am really sick." ${ }^{52}$ ( $p 49$ ), or were confused by conflicting information from different clinicians ${ }^{52}$.

Participants sought to connect with their clinicians to learn about their illness, contribute to decisionmaking and feel that their pain was acknowledged..$^{60}$ For some, learning about their condition and treatment options was an opportunity to exercise choice and advocate for themselves and their care ${ }^{57}$ Knowing details of treatments and procedures could also be comforting, and provide a sense of control. ${ }^{60}$ Female participants wanted to build a collaborative relationship by sharing and acknowledging health concerns: "I like my doctor to be my teammate — I just want them to know I'm smart and we can talk about this..." 60 (p 438)

Some felt needs that they voiced were not recognised by clinicians, and that a compassionate and genuine connection was missing from the interaction:

I have a terminal illness. I just wish you could step into my head for a minute to see what I'm feeling. Then you could understand the helplessness I feel, but you don't understand. I feel like, don't just look at my number, look at my face. I have a spirit. You have a spirit. I feel, you feel. ${ }^{60}$ ( $p$ 437)

Some participants noted that being proactive, engaged and informed about illness and the relationship with their clinicians helped them receive good care ${ }^{57}$, and that the "the basic attitude among medical [is] they take their jobs really seriously" ${ }^{57}$ ( $p$ 177).

\section{Differentiation between just and unjust punishment}

Keeping people in prison at the end-of-life was perceived as additional, unwarranted punishment which inflicted disproportionate suffering, and unfair: "I find that worse than a death sentence. ... It is a death penalty, indirectly. ... He will die in prison, so he is sentenced [to death]. He is sentenced twice, it's a double sentence. ${ }^{.55}$ ( $\mathrm{p}$ 11)

Compassionate release, in which frail and ill people nearing the end of their life are released from prison to die in the community, was considered the only humane solution to managing an expected death in custody. ${ }^{55}$ Participants thought that compassionate release "... [shows] a little respect." ${ }^{\text {.55 }} \mathrm{p}$ 13), and that frail and ill people did not belong in the harsh prison environment. ${ }^{54,55}$ Compassionate release was an opportunity to fulfil the person's last wishes to return home and be with family. ${ }^{55}$ Even in jurisdictions where compassionate release was possible, the process was lengthy, and some people died before application was processed. ${ }^{53}$

It was, however, also recognised that some people in prison could not be released at the end-of-life because of their offence. ${ }^{56}$ In these cases, or when people in prison did not have family members to care for them if released, an on-site prison hospice facility provided an acceptable alternative ${ }^{28,55}$, as "...he can die with dignity, because here [in general housing], he cannot die with dignity."

\section{Capacity to make choices is severely limited}

For those who feared death, extending life was paramount: "I want everything done to keep me alive. Even though my diagnosis is no way to live, I don't want to die ... [I would] rather live like this than not at all." ${ }^{\text {"52 ( }}$ 48)

However, many participants chose to minimise medical intervention(s) because "...if I can't be in the same shape [as I am now], then no CPR. Don't want a wheelchair or a machine." ${ }^{22}(\mathrm{p} 48)$. For others, their desire was to die peacefully, without pain, as "I have had my life ... now it is time for me to have death." ${ }^{2}$ ( $p$ 48) Resuscitation seemed pointless to some people with life sentences, because "why [would you] prolong life, when you are doing [serving a] life [sentence]."

The struggle of living in prison was so great for some that even though "I don't want to be dead, not at all, ... I don't want to be imprisoned, either. And those are in fact the two things I can choose from. ${ }^{28}$ ( $p$ 379) Suicide became a way escaping a life that had become meaningless: "... I am telling you, if someone would offer me to die now, I would say "yes, please" in an instant. I don't value this life anymore. ${ }^{28}$ ( $\mathrm{p} 379$ ) Some that voluntary assisted dying "should really be offered in prison. And not for medical reasons but really because of tedium of life, or rather tedium of prison. ${ }^{228}(p 380)$ 
Beyond contemplation of end-of-life care preferences, some participants also planned their funerals, which was a rare opportunity to make choices independent of the prison system. ${ }^{28}$

\section{2) Prison context complicates access to and provision of care}

\section{Physical environment complicates access to care}

Participants felt strongly that the prison environment was unsuitable for dying people, as "...there is no possibility in prison to care for someone [at the end-of-life]"55 ( $\mathrm{p} 10)$, and that "...someone with crutches or unable to walk belongs in a retirement or nursing home, but not here. ${ }^{.55}(p 10)$ The structural environment profoundly affected care availability. Maintaining dignity at the end-of-life outside of a dedicated hospice inpatient environment was difficult. ${ }^{55,57,58}$ Aside from limitations in medical and supportive care, people with palliative care needs were more affected by the privations of prison. ${ }^{54,56}$

Accessing regular medication can require people in prison to make their way to the dispensary and wait in line for their medications, which is difficult if unwell or frail:

I can just waltz upstairs and get my meds [medications], but you see guys trying to get up the stairs and ... they just can't do it. But they've got to go up [those] stairs every day to get their medication. ${ }^{54}$ ( $p$ 165)

Participants sometimes needed to choose between receiving their medication or having a meal as "...the pill line is very slow here..."57 ( $p$ 177), and no alternative was available.

Lack of medical equipment increased symptom burden, heightened anxiety and reduced quality of life. One participant described being forced to remain indoors because he needed an oxygen concentrator, and panicked when the electricity supply was interrupted, and he could not be transitioned to a tank for 20 minutes. When talking about the impact of this on his life, he said "I'm just miserable from trying to breathe.."57 ( $p$ 178) Poor quality bedding ${ }^{54,57}$ also caused "...a lot of back pain and undue pressure on my hip joints." ${ }^{.54}$ ( $\mathrm{p} 165$ ) that reduced quality of life.

People with palliative care needs were sometimes cared for in general housing units, and their peers could be asked to provide assistance with activities of daily living. ${ }^{24}$ The involvement of peers in personal care added to embarrassment:

So, the director asked other inmates if they were OK to take care of me. He had three mattresses stacked on the floor, and the two inmates agreed to empty my chamber pot. But I couldn't do it, I was blocked. I couldn't do it in the pot with other persons in the room. ${ }^{24}$ ( $p$ 69)

\section{Dying in prison adds complexity to mortality}

Contemplating death in prison provoked strong feelings that were complicated by incarceration; centring on shame, fear and acceptance.

Participants described feelings of grief and humiliation at the thought of dying in prison. Anticipatory grief about time lost to incarceration, inability to achieve redemption, and causing pain to family was often expressed. When reflecting on time spent in prison, some people thought that "...after 10 years it's going to be a waste to die here, ${ }^{" 58}$ ( $\left.\mathrm{p} 62\right)$ and that they "... would have the feeling of having missed life. ${ }^{28}$ ( $p$ 381). Others grieved the inability to make up for their prior actions and show that they had "...changed"53 ( $\mathrm{p} 236)$. As one person put it simply, "How can I die when I have yet to prove I am a good man?"53 ( $\mathrm{p} 237$ ).

Fear characterised many thoughts participants voiced about the prospect of dying in prison:

Without decent care, I will just get worse. I can tell, [and there is] nothing I can do about it. l've spent months trying to see a specialist on the outside and every day l'm getting sicker, frustrated, and one day closer to death, and when I wake up, there's no one here that gives a damn. ${ }^{58}(p 60)$ 
A perceived lack of support reinforced apprehension about the dying process. As one participant explained, "...My concern is not with what happens after death, but with the process of dying . . . the pain, the dignity." ${ }^{59}$ ( $\mathrm{p} 201$ ), while another said that being handcuffed after death was his "... main fear. ${ }^{, 59}$ (p210) Dying alone or without family was also deeply unsettling, as it would be the "...most terrible thing to happen... being alone to die by yourself." ${ }^{58}$ ( $p$ 63).

Many people who were afraid of dying tried to put it out of their mind, attempting "...not to think about it, at least. Because the more you think about it, the worse you feel."28 ( $p 377$ ) Staying occupied helped many people avoid thoughts about death. ${ }^{59}$

Feeling fearful was by no means universal. Some participants "...really [didn't] worry about dying. I think it would be a great relief." 59 ( $\mathrm{p} 211$ ) Death was framed as a reprieve from imprisonment, and a source of comfort, "...knowing [that] one day that I will not suffer any longer in this house."58 (p 64).

Some took a practical view of their mortality, acknowledging that "whether in prison or not, dying is part of life regardless of where you are." ${ }^{.58}$ ( $\mathrm{p} \mathrm{64)}$ and therefore "if it's my time to go, so be it." ( $\mathrm{p} 64$ ) Acceptance of death in prison allowed a degree of peace, and a wish to "make things as best I can while l'm here. I ain't never getting out. This is it." ${ }^{\text {"57 ( }}$ ( 179).

Religious beliefs assisted some people to cope with dying in prison, because "if a person's heart is right with God, they have no fear of death or eternity." ${ }^{58}$ ( $p$ 64) Those with agnostic views nearing the end-of-life were unsure if they "should have believed after all." ${ }^{28}$ ( $\mathrm{p} 378$ ).

\section{Discussion}

Prisons globally face a growing need for palliative and end-of-life care, which can be costly and difficult in the restrictive correctional system. This meta-synthesis has identified a number of key issues concerning access to and provision of palliative care from the perspective of people in prison under two analytical themes: Expectations versus experience of palliative care and the prison context complicates access to and provision of palliative care.

\section{Expectation of equitable palliative and supportive care}

People in prison expect to have their basic palliative care needs met, regardless of their sentence, or the prison context. Their priorities centred around clinical care, collaborative relationships with clinicians, a comfortable environment, adequate symptom management and access to basic social supports. As with general use of primary care in prison, access to and uptake of healthcare became a means of exercising choice and feeling in control. ${ }^{61}$

Issues with clinical care often focused on access to routine care, crisis response, and symptom management. Difficulties in accessing primary care consultations were reflective of other prison healthcare research, which similarly highlighted delays such as requirements for written applications. ${ }^{62,63}$

People in prison were entirely reliant on correctional officers and clinicians to provide assistance when a medical emergency occurred, but often felt that responses were too slow and risked avoidable deterioration or death. Experiencing an emergency where response was seemingly inadequate compounded fears about whether their own future medical needs would be met. As a result, people in prison had limited faith in the efficacy of medical interventions if they became ill, or experienced an emergency. Accelerated ageing, illness and death without possibility of adequate management became an inevitability while in prison, rather than a possibility.

Symptom management was similarly difficult, particularly in relation to pain. Many patients had experienced or seen others with unmanaged pain, and highlighted the reduction in quality of life. In research investigating pain management in prison, correctional clinicians cited difficulties in providing pain relief, because: accessing people in their cells was time-consuming, ${ }^{23}$ many requested unnecessary pain medication, ${ }^{61,63}$ and concerns that opioids would be trafficked. ${ }^{61,64}$ While pain management was complicated by multiple factors, unmanaged pain left people in prison with the perception that clinicians were apathetic towards self-reported pain. ${ }^{57,63}$ 


\section{Building a connection with clinicians in prison}

People in prison wanted a respectful, compassionate and empathetic relationship with their clinicians that fostered shared decision-making through meaningful communication. This was difficult to achieve because the power differential, lower social capital and lack of agency of people in prison produced an imbalanced relationship that hindered normal patient-clinician interaction. Clinicians also needed to balance custodial rules with caring responsibilities ${ }^{24}$ Fears of being perceived as being too sympathetic, ${ }^{27}$ feeling unsafe, ${ }^{65}$ or concerns about aggression ${ }^{66}$ contribute to clinicians withdrawing from making connections.

Communication was a crucial concern for people in prison who wholly relied on correctional clinicians for care. It was expected that communication would be polite, considerate, timely, and effectively convey complex medical information. Clear communication was crucial when people in prison wished to play an active role in their own care, and helped them to feel validated and supported during illness.

\section{Differentiation between just and unjust punishment}

In this analysis, current or future consumers of palliative care in prison strongly differentiated what constituted 'just' and 'unjust' punishment. While typical elements of prison such as physical incarceration and limited comforts were expected, circumstances where hardship was intensified because of unmet palliative care needs or the experience of dying in prison were considered an unfair supplementation of the intended punishment.

Punishment is a subjective and individual experience ${ }^{67}$ in which the apparent severity of punishment is governed by i) the difference between expected severity of punishment, and ii) the symbolic meaning attached to a punishment, such as physical incarceration and associated symbolism of being discarded by society. ${ }^{67}$

As a by-product of the prison environment, access to healthcare and accommodations for additional needs for people requiring palliative care are unavoidably limited, creating additional burdens for those with advanced, life-limiting illnesses. Whether intentionally or not, the restriction of healthcare access becomes part of the punishment. ${ }^{67}$

People in prison expected to receive adequate palliative care that would meet their needs while in prison. However, experiences such as delayed responses to medical crises often failed to meet these expectations and enhanced the difficulty of the situation. The effects of inadequate palliative care were enhanced by the symbolic meaning attached, that people in prison were not deserving of care. Holistically, the experience of illness, palliative care and dying in prison became a 'double burden'; 54 an unjustified and unfair additional punishment that denied the essential humanity of people in prison.

Indeed, people in prison cited their essential humanity as the key reason why they deserved to receive adequate palliative care, by clearly separating their personhood from their offence. In an environment where a sense of self and self-worth is systematically dismantled, ${ }^{68}$ people in prison with palliative care needs felt the need to highlight their essential humanity, and distinctly separate their personhood from their offence. Patients saw provision of palliative care as a basic human right that should be afforded to all people. ${ }^{69}$ Compassionate release, or at minimum specialised onsite hospice, was considered the only humane approaches to managing terminally ill and dying people in prison.

\section{Capacity to make choices is severely limited}

Despite the highly restrictive environment, people in prison still found ways to impose some semblance of control over their lives and deaths. While opportunities for self-determination are rare, some patients chose to proactively make choices where options were available.

Making an Advance Care Plan presented an opportunity both to work through feelings about death and preferences for care, and to ensure that their preferences were respected..$^{52}$ Degrees of fear and acceptance influenced care preferences. For those who were fearful, extending life was paramount; whereas for those who were accepting, death could present a means of relief from prison. Advance Care Planning choices were influenced by whether the person considered prison as preferable to 
death, or vice versa. Some also chose to plan their funerals or burials, in particular to ensure that they were not buried on prison grounds. ${ }^{59,70}$ Making choices about death was an opportunity for selfdetermination without the influence of the prison system for the first time since their imprisonment.

\section{Physical environment complicates access to care}

The physical environment in prison affects almost every aspect of care. Prison layouts and regimes are designed for young, healthy men. ${ }^{71}$ People in prison who have palliative care needs highlighted the additional challenges they faced because of their healthcare needs, complicating activities of daily living. ${ }^{72}$ Inability to access parts of the prison due to poor mobility is a barrier to performing activities of daily living, ${ }^{57}$ while environmental conditions such as poor temperature control, ${ }^{57,73}$ cleanliness, ${ }^{24,73}$ and noise 29,55 were common issues.

These were often the product of 'institutional thoughtlessness' ${ }^{74}$ wherein the specific needs of older and chronically ill people in prison are overlooked, or the increasing burden of age-related decline is not adequately considered. In these instances, the difficulties of imprisonment slowly increase proportionally to functional deterioration, but remain unobserved. People in prison believed that there was no possibility of providing adequate palliative care in the correctional environment; at least without dedicated hospice facilities. The perceived apathy of correctional services officers or clinicians led some people in prison to feel like when they were 'written off' or abandoned when they became ill, and no longer worthy of care. ${ }^{57}$

\section{Dying in prison adds complexity to mortality}

People in prison face additional complicating factors when facing their own mortality. Universal concerns such as fear of death and dying were omnipresent, but magnified in a restrictive and punitive correctional environment that prohibits many supports available to people in the community with palliative care needs.

In this meta-synthesis, fears focused primarily on death, the dying process, and the consequences of dying in the prison environment. The fear of dying alone in prison is profound, ${ }^{58,65,70}$ especially where seriously ill people in prison were housed in single cells. ${ }^{29}$ Both men and women experiencing severe chronic illness demonstrate quantifiably heightened death anxiety, ${ }^{58,59}$ accompanied by feelings of loneliness, anxiety, depression and denial. ${ }^{58,59,75}$

Disconnection with family at the end-of-life and dying without family present were distressing prospects. Interacting with family in the community and 'prison family' provided opportunities to give and receive psychosocial support and reduce isolation. Families were often separated by physical distance ${ }^{57,73}$ or estrangement, ${ }^{53}$ preventing them from providing psychosocial support to their relative in prison. Families has limited involvement in Advance Care Planning ${ }^{24}$ and opportunities for visitation were strictly limited. ${ }^{28}$

Feelings of hopelessness and inevitability of death became a significant psychological burden, which was amplified if the person had little faith they would receive adequate healthcare.

\section{Limitations}

Providing health care in prison varies widely both between, ${ }^{25,}{ }^{29}$ and even within ${ }^{27,}{ }^{28}$ countries, which limits, the capacity to generalise these findings. Data used for this analysis was drawn from quotes reported in literature rather than complete interview transcripts, which limits understanding of context and presents only a small proportion of all data collected. Additionally, disease-specific perceptions and experiences could not be explored as the nature of illness was rarely specified. The perspectives of clinicians' and correctional services personnel's perspectives regarding palliative care provision in prison should be addressed in further work, using similar methodology, to form an holistic representation of barriers and facilitators to care. Despite these limitations, review during analysis and discussion between authors indicated that themes identified within the available evidence were largely consistent across prison and jurisdictional settings. 
Articles pertaining to peer caregivers were also excluded from this work because of the volume of rich qualitative data on this topic, which could not be adequately explored in addition to the above analysis. Given this model is a key strategy for providing palliative care to people in prison in the US, and the profound effect it reportedly has on patients, caregivers, correctional personnel and broader prison culture, a further meta-synthesis of similar approach would be a valuable contribution to literature.

\section{What this study adds}

This research highlights that people in prison with palliative care needs perceive that life-limiting illness and death in prison is a further loss of liberty and punishment that goes beyond what is considered humane and dignified. People in prison believed that there is limited capacity to provide respectful and dignified care at the end-of-life in custody. Strategies should be designed and implemented to ensure that people in prison receive adequate psychological, social, emotional and physical support during the end-of-life, and that there is some capacity for them to make choices about their own care.

\section{Conclusion}

The prison environment changes the parameters of acceptable care through the culture of the total institution, wherein inhabitants are cut-off from the outside world and create an insular and hierarchical society. ${ }^{68}$ The ideal nature of palliative care in prison is currently ill-defined and care provision and availability varies widely despite the growing need. While the prison environment will inevitably limit care that can be provided by structural and organisational barriers, it is clear that current palliative care may not meet the needs of people in prison. It is critical, therefore, to identify what best-practice palliative care in prison looks like at each jurisdictional or country level, and to prioritise key principles of palliative care such as enhancing patient-provider communication, maintaining contact with family, and ensuring a person-centred approach to care.

\section{Declarations}

\section{Authorship}

JP and IS conceptualised study. IS conducted searches and screened included papers. IS, MD, NH, $\mathrm{SP}$ and JP completed data analysis and conceptualised themes. All authors contributed to manuscript preparation.

\section{Funding}

The author(s) disclosed receipt of the following financial support for the research, authorship, and/or publication of this article: This work was supported by the Australian Federal Government Department of Health National Palliative Care Projects initiative [grant number G01995].

\section{Declaration of conflicts of interest}

The Authors declare that there is no conflict of interest.

\section{Data management and sharing}

The search strategy, coding tree and COREQ quality appraisal are available as supplementary documents. 


\section{REFERENCES}

1. Maull F. Dying in prison: sociocultural and psychosocial dynamics. Hosp J, 1991; 7: 127-142. DOI: http://dx.doi.org/10.1080/0742-969X.1991.11882695.

2. Hammett TM, Harmon MP and Rhodes W. The burden of infectious disease among inmates of and releasees from US correctional facilities, 1997. Am J Public Health, 2002; 92: 1789-1794.

3. Linder JF, Enders SR, Craig E, et al. Hospice Care for the Incarcerated in the United States: An Introduction. J Palliat Med, 2002; 5: 549-552. Review. DOI: 10.1089/109662102760269788.

4. Maull FW. Issues in prison hospice: toward a model for the delivery of hospice care in a correctional setting. Hosp J, 1998; 13: 57-82.

5. Australian Bureau of Statistics. Prisoners in Australia, 2020. 2020. Sydney, NSW.

6. Prison Reform Trust. Prison: the facts Bromley Briefings, Summer 2014. 2014.

7. US Department of Justice. Aging of the State Prison Population, 1993-2013. 2016.

8. Zinger I and Landry M. Aging and dying in prison: an investigation into the experiences of older individuals in federal custody. 2019. Ottawa, Ontario.

9. Her Majesty's Inspectorate of Prisons. Justice Committee Inquiry into Older Prisoners. London: HMIP, 2014.

10. Her Majesty's Inspectorate of Prisons for Scotland. Who Cares? The lived experience of older prisoners in Scotland's prisons. Edinburgh: HMIPS, 2017.

11. House of Commons Justice Committee. Ageing prison population: Fifth Report of Session 2019-21. 2020.

12. Williams BA, Goodwin JS, Baillargeon J, et al. Addressing the Aging Crisis in U.S. Criminal Justice Health Care. J Am Geriatr Soc, 2012; 60: 1150-1156. DOI: 10.1111/j.1532-5415.2012.03962.x.

13. Baidawi $S$, Turner $S$, Trotter $C$, et al. Older prisoners - A challenge for Australian corrections. Trends Issues Crime Crim Justice, 2011: 1.

14. Australian Institute of Health and Welfare. Health and ageing of Australia's prisoners 2018. Report no. PHE 269, 2019. Canberra: AIHW.

15. Hoel A and Gelb K. Sentencing Matters: Mandatory Sentencing. Report no. 1921100265, 2008. Melbourne, Victoria: Sentencing Advisory Council.

16. Grant A. Elderly inmates: issues for Australia. Trends Issues Crime Crim Justice, 1999: 1.

17. Holland MM, Prost SG, Hoffmann HC, et al. U.S. Department of Corrections Compassionate Release Policies: A Content Analysis and Call to Action. Omega J Death Dying, 2020; 81: 607-626. DOI: 10.1177/0030222818791708.

18. Karch A and Cravens M. Rapid Diffusion and Policy Reform: The Adoption and Modification of Three Strikes Laws. State Polit Policy Q, 2014; 14: 461-491. DOI: http://dx.doi.org/10.1177/1532440014561867. 
19. Turner S and Trotter C. Growing old in prison?: A review of national and international research on Ageing Offenders, Corrections Research Paper Series, Paper No. 03 July 2010. Melbourne: DoJ, 2010.

20. Australian Institute of Health and Welfare. The health of Australia's prisoners 2018. Government. Report no. PHE 246, 2019. Canberra, ACT.

21. Rikard RV and Rosenberg E. Aging Inmates: A Convergence of Trends in the American Criminal Justice System. J Correct Health Care, 2007; 13: 150-162. DOI: 10.1177/1078345807303001.

22. Handbook of Death \& Dying. Thousand Oaks, California: SAGE Publications, Inc., 2003.

23. Turner M, Payne S and Barbarachild Z. Care or custody? An evaluation of palliative care in prisons in North West England. J Palliat Med, 2011; 25: 370-377. DOI: http://dx.doi.org/10.1177/0269216310393058.

24. Chassagne A, Godard A, Cretin E, et al. The Collision of Inmate and Patient: End-of-Life Issues in French Prisons. J Correct Health Care, 2017; 23: 66-75. Article. DOI: $10.1177 / 1078345816685084$.

25. Pazart L, Godard-Marceau A, Chassagne A, et al. Prevalence and characteristics of prisoners requiring end-of-life care: A prospective national survey. J Palliat Med, 2018; 32: 6-16. Article. DOI: 10.1177/0269216317721816.

26. Panozzo S, Bryan T, Collins A, et al. Complexities and constraints in end of life care for hospitalised prisoner patients. J Pain Symptom Manage, 2020.

27. Penrod J, Loeb SJ and Smith CA. Administrators' perspectives on changing practice in end-of-life care in a state prison system. Public Health Nurs, 2014; 31: 99108. DOI: 10.1111/phn.12069.

28. Handtke $V$ and Wangmo $T$. Ageing Prisoners' Views on Death and Dying: Contemplating End-of-Life in Prison. J Bioeth Inq, 2014; 11: 373-386. DOI: 10.1007/s11673-014-9548-x.

29. Papadopoulos I and Lay M. Current and emerging practice of end-of-life care in British prisons: findings from an online survey of prison nurses. BMC Palliat Care, 2016; 6: 101-104. Article. DOI: 10.1136/bmjspcare-2015-000880.

30. Ahalt C, Trestman RL, Rich JD, et al. Paying the Price: The Pressing Need for Quality, Cost, and Outcomes Data to Improve Correctional Health Care for Older Prisoners. J Am Geriatr Soc, 2013; 61: 2013-2019. Editorial. DOI: 10.1111/jgs.12510.

31. Baidawi S. Managing the health of an ageing prison population - a review of the challenges to be addressed by effective models of care: an Evidence Check rapid review brokered by the Sax Institute for the Justice Health and Forensic Mental Health Network. 2015.

32. Bedard R, Metzger $L$ and Williams B. Ageing prisoners: An introduction to geriatric health-care challenges in correctional facilities. Int Rev Red Cross, 2016; 98: 917-939. DOI: 10.1017/S1816383117000364.

33. Boyle BA. The Maryland Division of Correction hospice program. J Palliat Med, 2002; 5: 671-675. Article. DOI: 10.1089/109662102320880480.

34. Australian Healthcare Associates. Exploratory Analysis of Barriers to Palliative Care: Issues Report on People who are incarcerated. 2019. Melbourne, Australia: Australian Government Department of Health. 
35. Chiu T. It's about time: Aging prisoners, increasing costs and geriatric release, https://www.vera.org/downloads/Publications/its-about-time-aging-prisonersincreasing-costs-and-geriatric-release/legacy downloads/lts-about-time-agingprisoners-increasing-costs-and-geriatric-release.pdf (2010, accessed 17 June 2021 2021).

36. Ginnivan NA, Butler TG and Withall AN. The rising health, social and economic costs of Australia's ageing prisoner population. Med J Aust, 2018; 209: 422-424.

37. Inspector of Custodial Services. Old and inside: Managing aged offenders in custody. 2015. Sydney, NSW: Inspector of Custodial Services.

38. Mitchell A and Williams B. Compassionate Release Policy Reform: Physicians as Advocates for Human Dignity. AMA J Ethics, 2017; 19: 854-861. Article. DOI: 10.1001/journalofethics.2017.19.9.peer2-1709.

39. Ambitions for Palliative and End of life Care Partnership. Dying Well in Custody Charter: A national framework for local action. 2018. London, UK.

40. World Health Organisation. Strengthening of palliative care as a component of integrated treatment throughout the life course. 2014. Geneva: World Health Assembly.

41. Connor $S$ and Sepulveda Bermedo $M$. Global atlas of palliative care at the end of life, www.who.int/nmh/Global Atlas of Palliative Care.pdf (2014).

42. Quill TE and Abernethy AP. Generalist plus specialist palliative care-creating a more sustainable model. N Engl J Med, 2013; 368: 1173-1175.

43. McParland $C$ and Johnston BM. Palliative and end of life care in prisons: $A$ mixed-methods rapid review of the literature from 2014-2018. BMJ Open, 2019; 9 Review. DOI: 10.1136/bmjopen-2019-033905.

44. Thomas $\mathrm{J}$ and Harden $\mathrm{A}$. Methods for the thematic synthesis of qualitative research in systematic reviews. BMC Med Res Methodol, 2008; 8: 45. DOI: 10.1186/1471-2288-8-45.

45. Thorne S, Jensen L, Kearney MH, et al. Qualitative metasynthesis: reflections on methodological orientation and ideological agenda. Qual Health Res, 2004; 14: 1342-1365. 2004/11/13. DOI: 10.1177/1049732304269888.

46. Sladek R, Tieman J, Fazekas BS, et al. Development of a subject search filter to find information relevant to palliative care in the general medical literature. $J$ Med Libr Assoc, 2006; 94: 394-401.

47. Sladek RM and Tieman J. Applying evidence in the real world: a case study in library and information practice. Health Info Libr J, 2008; 25: 295-301. 2008/12/17. DOI: 10.1111/j.1471-1842.2008.00778.x.

48. Page MJ, McKenzie JE, Bossuyt PM, et al. The PRISMA 2020 statement: an updated guideline for reporting systematic reviews. BMJ, 2021; 372: n71. DOI: 10.1136/bmj.n71.

49. Australian Commission on Safety Quality in Health Care. National consensus statement: Essential elements for safe and high-quality end-of-life care. Sydney, NSW, Australia: ACSQHC, 2015.

50. Tran NT, Baggio S, Dawson A, et al. Words matter: a call for humanizing and respectful language to describe people who experience incarceration. BMC Int Health Hum Rights, 2018; 18: 1-6. 
51. Peacock M, Turner M and Varey S. 'We Call it Jail Craft': The Erosion of the Protective Discourses Drawn on by Prison Officers Dealing with Ageing and Dying Prisoners in the Neoliberal, Carceral System. Sociol-J Brit Sociol Assoc, 2018; 52: 1152-1168. Article. DOI: 10.1177/0038038517695060.

52. Sanders S, Stensland M and Juraco K. Agency behind bars: Advance care planning with aging and dying offenders. Death Stud, 2018; 42: 45-51. DOI: 10.1080/07481187.2017.1303552.

53. Sanders S and Stensland M. Preparing to Die Behind Bars: The Journey of Male Inmates With Terminal Health Conditions. J Correct Health Care, 2018; 24: 232-242. DOI: http://dx.doi.org/10.1177/1078345818780686.

54. Turner M, Peacock M, Payne S, et al. Ageing and dying in the contemporary neoliberal prison system: Exploring the 'double burden' for older prisoners. Social Science \& Medicine, 2018; 212: 161-167. DOI: 10.1016/j.socscimed.2018.07.009.

55. Handtke V, Bretschneider W, Elger B, et al. The collision of care and punishment: Ageing prisoners' view on compassionate release. Punishm Soc, 2017; 19: 5-22. Article. DOI: 10.1177/1462474516644679.

56. Turner M and Peacock M. Palliative Care in UK Prisons: Practical and Emotional Challenges for Staff and Fellow Prisoners. J Correct Health Care, 2017; 23: 56-65. Article. DOI: 10.1177/1078345816684847.

57. Loeb SJ, Penrod J, McGhan G, et al. Who Wants to Die in Here?

Perspectives of Prisoners With Chronic Conditions. J Hosp Palliat Nurs, 2014; 16 : 173-181. DOI: 10.1097/NJH.0000000000000044.

58. Deaton D, Aday $\mathrm{RH}$ and Wahidin A. The effect of health and penal harm on aging female prisoners' views of dying in prison. Omega J Death Dying, 2009; 60: 51-70.

59. Aday RH. Aging prisoners' concerns toward dying in prison. Omega J Death Dying, 2005; 52: 199-216.

60. Enders SR, Paterniti DA and Meyers FJ. An approach to develop effective health care decision making for women in prison. J Palliat Med, 2005; 8: 432-439. DOI: $10.1089 / j p m .2005 .8 .432$.

61. Feron J-M, Lac Hong Nguyen T, Pestiaux D, et al. High and variable use of primary care in prison. A qualitative study to understand help-seeking behaviour. Int J Prison Health, 2008; 4: 146-155. DOI:

http://dx.doi.org/10.1080/17449200802264696.

62. Plugge E, Douglas N and Fitzpatrick R. Patients, prisoners, or people? Women prisoners' experiences of primary care in prison: a qualitative study. $\mathrm{Br} J$ Gen Pract, 2008; 58: e1-e8.

63. Condon L, Hek G, Harris F, et al. Users' views of prison health services: a qualitative study. J Adv Nurs, 2007; 58: 216-226.

64. Hoffman HC and Dickinson GE. Characteristics of Prison Hospice Programs in the United States. Am J Hosp Palliat Care, 2011; 28: 245-252. DOI:

$10.1177 / 1049909110381884$.

65. Depner RM, Grant PC, Byrwa DJ, et al. "People don't understand what goes on in here": A consensual qualitative research analysis of inmate-caregiver perspectives on prison-based end-of-life care. J Palliat Med, 2018; 32: 969-979. DOI: $10.1177 / 0269216318755624$. 
66. Walsh E, Butt C, Freshwater D, et al. Managing pain in prison: staff perspectives. Int J Prison Health, 2014.

67. Sexton L. Penal subjectivities: Developing a theoretical framework for penal consciousness. Punishm Soc, 2015; 17: 114-136. DOI:

10.1177/1462474514548790.

68. Goffman E. Asylums: essays on the social situation of mental patients and other inmates. 1 ed. Garden City, N.Y: Anchor Books, 1961.

69. Brennan F. Palliative Care as an International Human Right. J Pain Symptom Manage, 2007; 33: 494-499. DOI:

https://doi.org/10.1016/j.jpainsymman.2007.02.022.

70. Kanbergs A, Ahalt C, Cenzer IS, et al. "No One Wants to Die Alone":

Incarcerated Patients' Knowledge and Attitudes About Early Medical Release. J Pain Symptom Manage, 2019; 57: 809. DOI:

http://dx.doi.org/10.1016/j.jpainsymman.2018.12.335.

71. Marti I, Hostettler $U$ and Richter M. End of Life in High-Security Prisons in Switzerland: Overlapping and Blurring of "Care" and "Custody" as Institutional Logics. J Correct Health Care, 2017; 23: 32-42. Article. DOI:

10.1177/1078345816684782.

72. Bolano M, Ahalt C, Ritchie C, et al. Detained and Distressed: Persistent Distressing Symptoms in a Population of Older Jail Inmates. J Am Geriatr Soc, 2016; 64: 2349-2355. DOI: 10.1111/jgs. 14310.

73. Loeb S, Hollenbeak C, Penrod J, et al. Care and Companionship in an Isolating Environment: Inmates Attending to Dying Peers. J Forensic Nurs, 2013; 9: 35.

74. Crawley E. Institutional Thoughtlessness in Prisons and Its Impacts on the Day-to-Day Prison Lives of Elderly Men. J Contemp Crim Justice, 2005; 21: 350-363. DOI: $10.1177 / 1043986205282018$.

75. Yampolskaya S and Winston N. Hospice care in prison: general principles and outcomes. Am J Hosp Palliat Care, 2003; 20: 290-292p. DOI:

10.1177/104990910302000411. 